\title{
Optimizing Dehydration Conditions of Cow's and Goat Milk Yogurt Powder
}

\author{
Ibrahim Aldaw Ibrahim, Rifda Naufalin, Erminawati, Hidayah Dwiyanti
}

\begin{abstract}
Yogurt is one the importance the most common fermented dairy products widely consumed worldwide, mmostly studies are about in how to longer the yogurt shelf life, this study purposed to drying cow and goat milk yogurt by freeze dryer to provide alternative method don't have effect on yogurt compounds and lactic acid bacteria cell, and to identification the influence of stirring and time on yogurt powder compounds, the International Official Analytical Chemistry Association (AOAC) and the Indonesian National Standard (SNI) methods were used to analyze the chemical composition of yogurt powder, Cow's and goat milks were mixed in rate 25:75 (v/v), inoculum with culture $15 \%(v / v) S$. therophillus, L. acidophilus, $L$. burgaricus (1:1:1), and incubated at $46^{\circ} \mathrm{C}$ for $8 \mathrm{~h}$.Yogurt was dryed by freeze dryer at $-73^{\circ} \mathrm{C}$ for 16,19 , and 22 hours on 4,5 , and 3 batches with stirring respectively, The results obtained from this study that the best drying method of cow and goat yogurt treated by freeze dryer was19h., drying by freeze at batches with stirring have no significant effect on amount of bacteria cells, moreover, it is an excellent method to preserve the desirable microbiological properties in yogurt, and decreased the drying time and improving quality of final product.
\end{abstract}

Keywords: Yogurt, Dehydration, Nutritional value

\section{INTRODUCTION}

Yogurt is one the importance the most common fermented dairy widely consumed worldwide. Yogurt from cow's milk is widely consumed all over the world. Moreover, there is a great demand for alternative to cow's milk due to allergy-related problems, gastrointestinal disorders and the desire for new dairy products (Weerathilake et al, 2014), (Shu et al, 2015).

Goat milk have a higher digestibility and less sensitivity digestion than cow's milk, in addition highest content of short-chain fatty acids in milk fat, high iron and zinc content magnesium and antibacterial characteristics, additionally, these benefit can be further enhanced by using goat's milk as a method of providing probiotics (Slacanac et al., 2010), (Kumar et al., 2012e), (Zenebe et al., 2014). Goat's milk is the third largest dairy supplier after cow's milk and buffalo milk, which has multiple functions in nutrition, health and diet. Gradually became the product of choice for high-end consumers. In general, there is no insignificant difference in

Revised Manuscript Received on January 5, 2020.

* Correspondence Author

Ibrahim Aldaw Ibrahim, Postgraduate Agricultural Science Doctoral Program, Universitas Jenderal Soedirman, Indonesia, E-mail: Ibrahim.sudann@gmail.com.

Rifda Naufalin' Food Science and Technology, Univeristas Jendural Soedirman/ Purwokerto, Indonesia. E-mail: rnaufalin@yahoo.co.id.

Erminawati, Food Science and Technology, Univeristas Jendural Soedirman/ Purwokerto, Indonesia. E-mail: erminawati.w@gmail.com.

Hidayah Dwiyanti, Food Science and Technology, Univeristas Jendural Soedirman/ Purwokerto, Indonesia. E-mail: hidayah_unsoed@yahoo.com. the nutritional value of goat's and cow's milk. Due to its nutritional properties and better metabolism, goat milk has been proposed as an ideal alternative for allergy and infant patients based on cow's milk and other food sources (Guowei et al., 2016), (Haenlein and Anke, 2011).

Yoghurt powder is dehydrated products producing by one of drying methods based on removal water or reduces water activity of finally

product. Which increase the shelf life of food. Yogurt powder can be prepared in various methods, the most use such as spray-drying, freeze-drying. Freeze dried yogurt has capable to keep its nutritional values for up to two years with storage it at $4^{\circ} \mathrm{C}$. Yogurt powder has many applications in making instant yogurt powder and in food industries such as Bakery, confectionary and healthy drinks (Kumar and Mishra, 2004), (Balkir, 2011), (Krasaekoopt and Bhatia, 2012).

Freeze drying and freeze concentration has capacity of reduce water activity of foods a with keep nutritional and sensory qualities (Khalisanni, 2011), (Aalaei et al., 2016). For obtain longer shelf life and good quality of product, the yoghurt powder can be stored at low temperatures and dry condition (Chutrtong, 2015), (Abbas et al., 2014). The Thermal stability studies that both processes of freeze-drying and spray-drying not has influence in behaviours of whey protein (Vincenzetti et al., 2018). This study purposed to drying cow and goat milk yogurt by freeze dryer to provide alternative method don't have effect on yogurt compounds, viable cells of lactic acid bacteria lactic, and to determine the effect of time with stirring on yogurt powder compounds.

\section{MATERIAL AND METHOD}

\section{A. Preparation milk and yogurt samples}

The cultures of S. thermophillus, L. acidophilus and L. bulgaricus obtained from livestock technology Laboratory faculty of animal hasbandury, Universitas Jendural Soedirman. In order to preparing milk samples, they were treated cow and goat milks at $85^{\circ} \mathrm{C}$ for $5 \mathrm{sec}$ and cooled to $45^{\circ} \mathrm{C}$, then cow and goat milks was mixed 25:75 (v/v), incoulated with culture (inoculum size $15 \%(\mathrm{v} / \mathrm{v})$ ), then were fermented at temperature $46^{\circ} \mathrm{C}$ for $8 \mathrm{hr}$. the yogurt samples storage at $4^{\circ} \mathrm{C}$ to $12 \mathrm{hr}$. After that yogurt samples preparing to dry by freeze dryer.

\section{B. Dehydration process}

All Yogurt samples were separated to three groups, and coded A, B and C. Then put in small topless $24 /$ liter, and were freeze at $-81^{\circ} \mathrm{C}$ before processing. Yogurt samples were dehydrated by freeze dryer (Virtis, model bench top 2kxc) at $-72^{\circ} \mathrm{C}$ for three times 16,19 ,

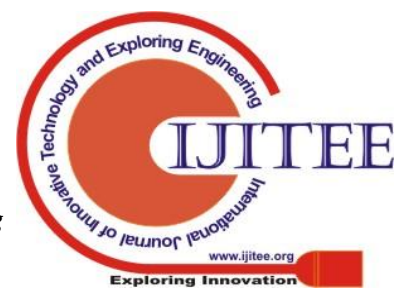


and $22 \mathrm{hr}$ with stirring 4, 5, 3 times respectively.

\section{Determination proximate and microbiological parameters}

The proximate analysis of yogurt powder was determined according to the procedures recommended by the International Official Analytical Chemistry Association AOAC, (2005), and the Indonesian National Standard SNI, (2011). Total lactic acid bacteria were analyzed according to methods of Pestana et al., (2015), as described by Ehirim and Onyeneke (2013).

\section{Sensory evaluation}

The panel test was measured according to the 9 point hedonic scale, and was used to illustrate team members (20 participants from Food Science and Technology Students), acceptance of taste, smell, texture, color, and overall acceptability.

According to the methods of (Santos et al., 2018).

\section{E. Statistical Analysis}

The analysis of variance (ANOVA) tests were performed to evaluate the difference between data by using Microsoft Excel version (2013). The means were separated by Duncan multiple range test. Significant differences were determined at $(\mathrm{P} \geq 0.05)$.

\section{RESSULTS AND DISCUSSION}

\section{A. Yogurt powder recovery rate}

\section{Yield of freeze dried Yogurt (\%)}

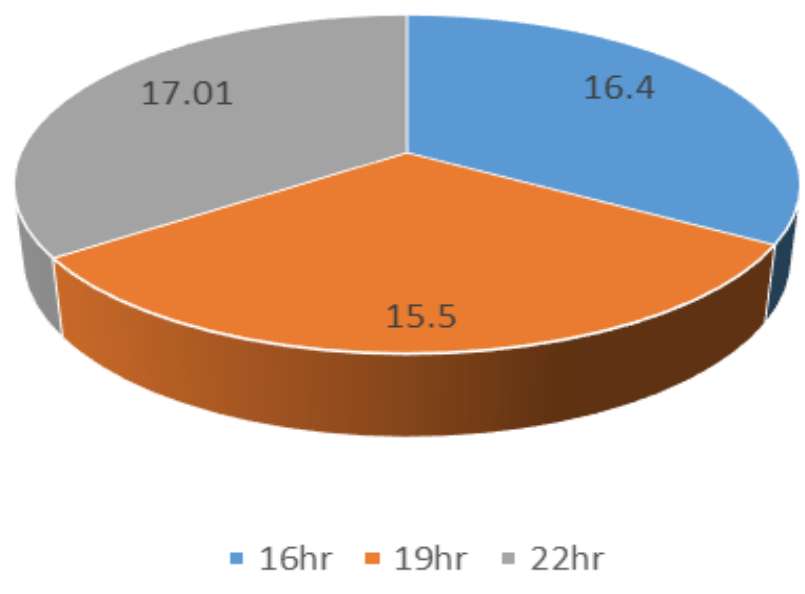

Figure1. Yogurt powder recovery rate

Figure1. Showed the results of powder yogurt yield of freeze dried yogurt. The dehydration ratio of cow and goat milk yogurt powder was dryer at 16, 19, 22 hours, were 16.4, 15.5, and $17.01 \%$ respectively. The dehydration ratio of cow and goat yogurt for $22 \mathrm{~h}$ is higher yields compare with other treatments. And dehydration ratio of yogurt samples treated at $19 \mathrm{~h}$ is lowest to compare with $16,22 \mathrm{~h}$. These different may due to conditions of dehydration, capacity used for dehydration and water content in final yogurt powder. Moreover, this different due to amount of stirring during dehydration and count of batches during drying yogurt samples, sample A stirring 4 times, B stirring 5 times, and C stirring 3times. This result comparable with Santos et al., (2018), who found the yield of freeze dried yogurt was $18 \%$.

\section{B. Composition of cow and goat yogurt powder}

The composition results of yogurt powder samples were shown in Table1. The protein content of cow and goat yogurt powder were $17.11,20.07$, and 16.54 respectively. There were significant difference $(\mathrm{P} \geq 0.05)$ between cow and goat yogurt powder. The result shown the time had significant influence on protein content of powder yogurt. This result is incomparable with Sulaksono et al., (2013) who mentioned that the protein content of yogurt powder treated by spray dryer was $31.2 \%$, and Krasaekoopt and Bhatia, (2012), they reported that the protein content $f$ freeze dried yogurt was ranging $33.0-36.0 \%$. These difference in protein content due to destruction protein in yogurt as well as the destruction of hydrogen bonds and non-polar hydrophobic reaction. Then lead damage the molecule bond and milk protein denaturation and coagulation occurred during the drying process (Damasceno et al., 2008).

Table1. Chemical composition of cow and goat yogurt powder

\begin{tabular}{cccccc}
\hline Samples & Protein & Fat & Ash & Moisture & Carbohydrate \\
\hline A & $17.11^{\mathrm{b}}$ & $30.14^{\mathrm{b}}$ & $0.23^{\mathrm{b}}$ & $18.49^{\mathrm{b}}$ & $33.96^{\mathrm{b}}$ \\
B & $20.07^{\mathrm{a}}$ & $36.03^{\mathrm{a}}$ & $0.12^{\mathrm{c}}$ & $7.00^{\mathrm{c}}$ & $36.67^{\mathrm{a}}$ \\
C & $16.54^{\mathrm{c}}$ & $28.46^{\mathrm{c}}$ & $0.89^{\mathrm{a}}$ & $20.87^{\mathrm{a}}$ & $33.18^{\mathrm{c}}$
\end{tabular}

$\mathrm{A}=$ Dehydration for $16 \mathrm{hr}, \mathrm{B}=$ Dehydration for $19 \mathrm{hr}, \mathrm{C}=$ Dehydration for $22 \mathrm{hr}$ Heat treatment affects in the molecular structure of milk protein at the surface of oil-in water emulsions in water and in the aqueous medium (Raikos, 2010), (Paskov et al). The fat result of cow and goat yogurt powder were 30.14, 36.03, and $28.46 \%$, respectively. The result shown in table 2 reveals that the fat content of yogurt powder were remarkably affected by time and stirring applied to it. However, fat content of group treated by $22 \mathrm{hr}$ with three times stirring were significantly $(\mathrm{P} \leq 0.05)$ higher followed by $(16 \mathrm{hr}$ with four times stirring) and (19hr with five times stirring). Moreover, the fat content in sample B was remarkably higher $(\mathrm{P} \leq 0.05)$ than that of $\mathrm{A}$ and $\mathrm{C}$ yogurt powder. This results showed the time and stirring had significant effect on increased fat content in yogurt powder. This result is no similar with Krasaekoopt and Bhatia, (2012), they reported that the protein content $\mathrm{f}$ freeze dried yogurt was ranging 1.2.0 - 2.0\%, and comparable with Sulaksono et al., (2013) who noted the fat content of powder of yogurt treated by spray dryer was $36.2 \%$. This different in fat content due to oxidation in fat by drying processing. The moisture content of powder yogurt were $18.49,7.00$, and $20.87 \%$ respectively. Form this result there were significant difference $(\mathrm{P} \geq 0.05)$ between each powder yogurt samples. The results show that time and stirring had significant effect on moisture content of yogurt powder production, but it varied with period time used in this research. The moisture was in a range of $7.00-$ $20.87 \%$. these results is compatible to the value reported by Sulaksono et al., (2013) they found the moisture content of powder yogurt was $10.3 \%$,

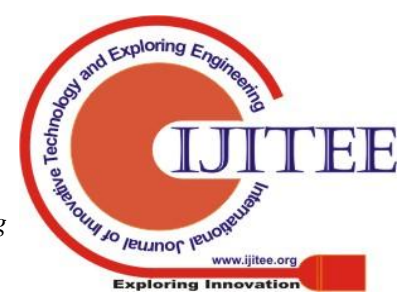


and Krasaekopt and Bhatia, (2012) they mentioned that the moisture content of powder yogurt was ranged between $8.5-$ $8.6 \%$. These results shown the greater the count of stirring and at batches during not continuous drying could lead drying process faster. The results in ash content of yogurt powder were $0.23,0.12$, and $0.89 \%$ respectively. The result obtained in this study reveals that the fat content of yogurt powder were remarkably affected by time and stirring applied to it. However, fat content of group treated by $19 \mathrm{hr}$ with three five stirring were significantly $(P \leq 0.05)$ higher followed by (16hr with four times stirring) and (22hr with three times stirring). Moreover, the fat content in sample $\mathrm{C}$ was remarkably higher $(\mathrm{P} \leq 0.05)$ than that of $\mathrm{A}$ and $\mathrm{B}$ yogurt powder. This result showed the time and stirring had significant effect on Decreased fat content in yogurt powder. This result is no similar with Krasaekoopt and Bhatia, (2012), they reported that the protein content $f$ freeze dried yogurt was ranging $7.0-8.0 \%$, Sulaksono et al., (2013) who noted that the fat content of yogurt powder treated by spray dryer was $6.7 \%$.

\section{Microbiological characteristics}

The bacteria counts of the yogurt powder samples shown in Figure2. The results of total lactic acid bacteria of yogurt powder were $5.9,5.7$, and $5.7 \times 10^{6} \mathrm{cfu} / \mathrm{g}$ respectively. This results showed there were no significant effect on viable cells of lactic acid bacteria in all samples of yogurt powder. These results similar with Santos et al., (2018) who reported the freeze-drying can preserving the microbiology, nutritional value and sensory properties of yogurt, Krasaekoopt and Bhatia, (2012), they recommended that the viable bacteria cells in freeze dried yogurt was $5.6 \times 10^{7} \mathrm{cfu} / \mathrm{g}$, and incomparable with Sulaksono et al., (2013) who reported the viable bacteria cells in freeze dried yogurt was $12 \times 10^{7} \mathrm{cfu} / \mathrm{g}$. According to the Identity and Quality Standards of fermented milk - MARA minimum counts of $10^{7} \mathrm{CFU} / \mathrm{g}$ viable bacteria cells as required in the yogurt until its consumption. In line with these requirements, the bacteria counts of cow and goat yogurt powder (Fig1) were similar with required by legislation for fermented milk. Therefore, the freeze-drying is an excellent method for drying yogurt.

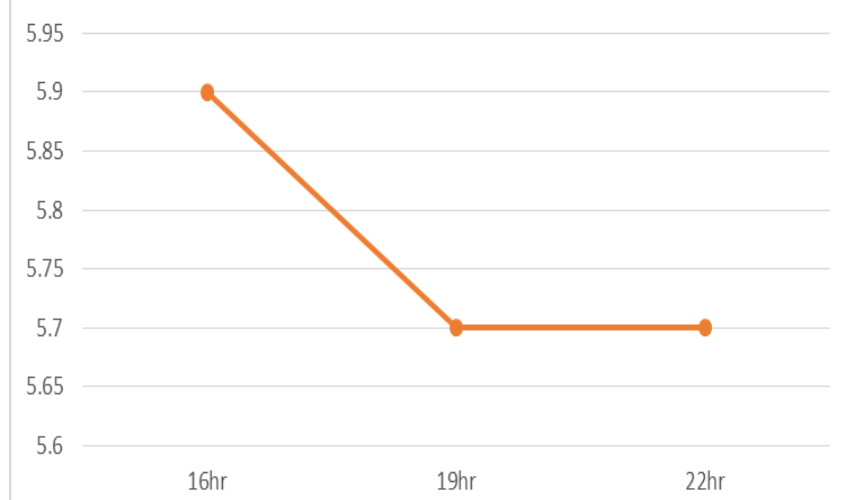

Figure2. Effect of dehydration time and stirring on viable bacteria cells $\left(10^{6} \mathrm{cfu} / \mathrm{g}\right)$

\section{Organoleptic test}

Table2. Sensory test of freeze cow and goat yogurt powder

\begin{tabular}{lcccc}
\hline Samples Color & $\begin{array}{c}\text { Textur } \\
\text { e }\end{array}$ & Aroma & $\begin{array}{c}\text { Tast } \\
\text { e }\end{array}$ & $\begin{array}{c}\text { Overall } \\
\text { Acceptability }\end{array}$ \\
\hline
\end{tabular}

\begin{tabular}{cccccc} 
A & 7.17 & 7 & 6.7 & 6.88 & 7.7 \\
B & 7.64 & 7.7 & 7.23 & 7.35 & 7.76 \\
C & 7.11 & 6.29 & 6.94 & 7 & 7.76 \\
\hline A = Dehydration for 16hr, B = Dehydration for 19hr, C = Dehydration for 22hr
\end{tabular}

The sensory profiles of cow and goat yogurt powder shown in Table2. The color of cow and goat yogurt powder treated at 16, 19, and 22 hours with stirring were white to white yellowish. The aroma of yogurt powder produced at 16, and 19 with four and five times stirring was better accepted than yogurt powder produced at $22 \mathrm{hr}$ with three times stirring. The taste of yogurt powder obtained was better in yogurt powder produced at 16 , and $19 \mathrm{hr}$ than $22 \mathrm{hr}$. The overall acceptability of yogurt powder produced at $19 \mathrm{hr}$ with five stirring was liked very much.

\section{CONCLUSION}

This present study established that the not continuous drying (batches) with stirring during dehydration yogurt has significant effect on increasing protein and fat content, and decreasing ash and moisture content in final product. Moreover, drying yogurt by freeze dryer at $-73^{\circ} \mathrm{C}$ for $19 \mathrm{hr}$ with batches and stirring up to 5times is better. However, it is suitable method for drying yogurt, which is decreased the drying time and improving the Quality of final product.

\section{AKNOWLEDAGEMENT}

The authors are grateful for the Research Institute and Community Service (LPPM), Agricultural Technology, and Central Laboratories of Universitas Jenderal Soedirman for their funding and support for completing this study.

\section{REFERENCES}

1. Weerathilake, W. A., Rasika, D.m., Ruwanmali, J.k., Munasinghe, M.A. (2014). THE evolution, processing, varieties and health benefits of yogurt, international Journal of Science and Publications. ISSN: 2250-3153.

2. Shu, G., Lei, N., Wan, H., Chen, H., Li, H., (2015). Effect of temperature and inoculum size on goat yogurt fermented by Bifidobacterium Bifidumand Lactobacillus Casei, Carpathian Journal of Food Science and technology, vol, 7(4), 28-35. 5.

3. Slacanac, V., Bozanic, R., Hardi, J., Rezessyne, S. J., Lucan, M., Krstanovic, V., (2010). Nutritional and therapeutic value of fermented caprine milk, International Journal of dairy technology, vol, 63(2), 171-189, doi.org/10.1111/j.1471-0307.2010.00575.

4. Kumar, S., Birendra, K., Rajesh, K., Suryamani, K., (2012). Featur eatures nutritional $\mathrm{F}$ eatur ES of goat milk review Eview, Indian Journal dairy science, 65(4), 266-273.

5. Zenebe, T., Nejash, A., Tadele, K., Girma, K., (2014). Review on medicinal and nutritional values of goat milk, Academic Journal of nutrition 3(3), 30-39.

6. Guowei, S., Chunju, B., Chen, H., Wang, W., Yang, H., (2016) Fermention optimization of goat milk with lactobacillus Acidophilus and Bifidobacterium Bifidum by Box-Behnken Design, Acta Sci. Pol.Technol. Aliment, 15(2), 151-159, DOI: 10.17306/J.AFS.2016.2.15

7. Haenlein, G. F. W., Anke, M., (2011). Mineral and trace element research in goats: a review, small Rum, Res, 95, 2-19

8. Kumar, P., Mishra, H.N., (2004). Yoghurt powder-A review of process technolgy, storate and utilization, Food and Bioproducts Processing, 82(C2), 133-142, 0960-3085/04/S30.00+0.00.

9. Balkir, P., Sakin, M., Koc, B., Kaymak-Ertekin, F., (2011). Storage stability of spray-dried yogurt powder, Milchwissenschaft, 66(2), 159-162.

10. Krasaekoopt, W., Bhatia, S., (2012). Production of yogurt powder using foam-mat drying, 
AU Journal of Technology, 15(3), 166-171.

11. Khalisanni, K., (2011). An overview of lactic acid bacteria, International Journal of Biosciences (IJB), 1(3), 1-13.

12. Aalaei, K., Marilyn, R., Ingegerd, S., (2016). Storage stability of freeze-dried, spray-dried and drum-dried skim milk powders evaluated by Availble lysine, LWT-Food Science and Technology, 73. 675-82. doi.org/10.1016/i.lwt.2016.07.011.

13. Chutrtong, J., (2015). Survival of probiotic bacteria in freeze-dry yogurt starter cultures storage at 4 and 30 degree celsius, Procedia-Social and Behavioral Sciences, 191, 2219-25.

14. Abbas, H., Hassan, F. H., Abd El-Gawad, Enab, A., (2014) Physicochemical Characteristics of goat's milk, Igarss, 11(1), 307-17.

15. Vincenzentti, S., (2018). Effect of Freeze-drying and spray-drying on donkey milk volatile compounds and whey proteins stability, LWT-Food Science and Technology, 88:189-95, doi.org/10.1016/j.lwt.2017.10.019

16. A.O. A. C., (2005). Official methods of analysis. The association of official analytical chemists, $16^{\text {th }}$ Edition, North Fredrick Avenue Gaithersburg, Maryland, USA.

17. Standard National Indonesia, (2011). Cow'S Fresh Milk, part1, SNI 3141.1:2011, Jakarta.

18. Pestana, J, M., Gennari, A., Monteiro, B. W., Lehn, D. N., Volken de Souza, C.F., (2015). Effect of pasteurization and Ultra-High temperature processess on proximate composition and fatty acid profile in bovine milk, American Journal of Food Technology, vol, 10(6), 265-272, DOI: 10.3923/ajft.2015.265.272.

19. Ehirim, F. N., Onyeneke, E. N., (2013). Properties of yoghurt manufactured with cow milk and gaot milk, Natural and Applied Sciences, ISSN-L: 2223-9553, ISSN: 2223-9944.

20. Santos, G. D., Nogueira, R. I., Rosenthal, A., (2018). Powdered yoghurt produced by spray drying and freeze drying: a review, Brazilian Journal of Food Technology, 21(0), doi:10.1590/1981-6723.12716.

21. Sulaksono, A. C., Kumalaningsih, S., Wignyanto, S. I., (2013). Production and Processing of Yoghurt Powder Using Foam-Mat Drying, Food and Public Health, 3(5): 235-239. DOI: 10.5923/j.fp h.20130305.01.

22. Damasceno, L. F., Fermandes, F. A. N., Magalhaes, M. M. A., Brita, E. S., (2008). Evaluation and Optimization of Non Enzymatic Browning of "Cajuina" During Thermal Treatment, Brazilian Journal of Chemical Engineering, Vol. 25, No. 02, 313 - 320, ISSN 0104-6632.

23. Raikos, V., (2010). Effect of heat treatment on milk protein functionality at emulsion interaces. A review, Food Hydrocoll, 24(4), 259-65.

24. Paskov, V., Karsheva, M., Pentchev, I., (2010). Effect of starter culture and homogenization on the Rheological properties of yoghurt, Journal of the University of Chemical Technology and Mettallurgy, 1(January 2010), 59-66.

\section{AUTHORS PROFILE}

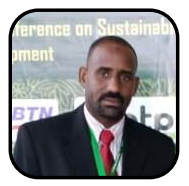

Ibrahim Aldaw Ibrahim, Postgraduate Agricultural Science Doctoral Program, Universitas Jenderal Soedirman, Indonesia, (1. Influence of Different Extraction Methods on Physic-chemical Characteristics and chemical composition of Coconut Oil (Cocos nucifera L), 2. Study on Physico-Chemical Characteristics of Some Plant Oils for Raw Materials of Biodiesel, 3. (Under proceeding process-ICMA-SURE 2019) Effect of fermentation temperature and culture concentration on microbial and physicochemical properties of cow and goat milk yogurt.

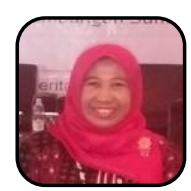

Rifda Naufalin, Professor at Department of Food Science and Technology, Faculty of agriculture, Head of Research Institute and Community Service (LPPM) Universitas Jenderal Soedirman - Indonesia, She supervised a lot of research for undergraduate and graduate students and provided counseling to serve the community, and have more research projects. Moreover, she has more research work and publications.

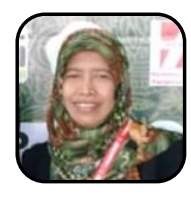

Erminawati, Co-professor at Department of Food Science and Technology, Faculty of agriculture, Universitas Jenderal Soedirman - Indonesia, She supervised a lot of research for undergraduate and graduate students and provided counseling to serve the community, and have more research projects. Moreover, she has more research work and publications.

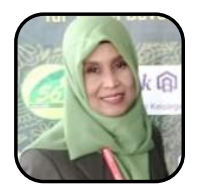

Hidayah Dwiyanti, Co-professor and Head of Department of Food Science and Technology, Faculty of agriculture, Universitas Jenderal Soedirman - Indonesia, She supervised a lot of research for undergraduate and graduate students and provided counseling to serve the community, and have more research projects. Moreover, she has more research work and publications. 